\title{
Analisis Indikator Fundamental Ekonomi Daerah di Kalimatan Barat: Pertumbuhan Ekonomi, Pendapatan Perkapita dan HDI
}

\author{
Nurul Bariyah* \\ Universitas Tanjungpura
}

\begin{abstract}
This study aimed to identify the profile and classification of districts and cities in West Kalimantan based on indicators of local economic fundamentals such as economic growth, per capita income and the Human Development Index (HDI). Secondary data were obtained from the BPS West Kalimantan and other related agencies for the years 2005 - 2011. In the processing of secondary data to answer the purpose, this study uses local typology analysis tools to determine the pattern and structure of economic growth in each region (Kuncoro, 2004) which divides area into four categories: (1) regions with high-income and high economic growth; (2) regions with high-income and low economic growth; (3) regions with low-income and high economic growth; and (4) regions with low income and low economic growth.The research found development gaps between the City of West Kalimantan (Pontianak and Singkawang) and other districts where both cities have high-performance in economic growth, income per capita and HDI. None of the districts that have high performance in all three indicators. 11 other districts have diverse performance. Policy development at the district and municipal level should be based on development goals on a scale of local, provincial and national levels with a convergent pattern. This will facilitate the development of the region in the future.
\end{abstract}

Keywords: economic growth, per capita income, human development index, local economic fundamental

\section{PENDAHULUAN}

Perekonomian Kalimantan Barat mengalami perkembangan yang fluktuatif dari waktu ke waktu seiring dengan perkembangan ekonomi Indonesia sebagaimana terlihat Grafik 1. Pada tahun 2004 pertumbuhan ekonomi Provinsi Kalimantan Barat berada pada tingkat sedikit lebih rendah dari tingkat pertumbuhan ekonomi nasional, dengan perbedaan $0,17 \%$. Tahun-tahun berikutnya tingkat pertumbuhan ekonomi Provinsi Kalimantan Barat berjalan hampir parallel di bawah tingkat pertumbuhan ekonomi Nasional.

\footnotetext{
* Korespondensi: Nurul Bariyah, Jurusan Ilmu Ekonomi, Fakultas Ekonomi, Universitas Tanjungpura, Jalan Prof. Dr. H. Hadari Nawawi, Pontianak, Indonesia. Email: nurulb_hamzar@yahoo.com.
} 


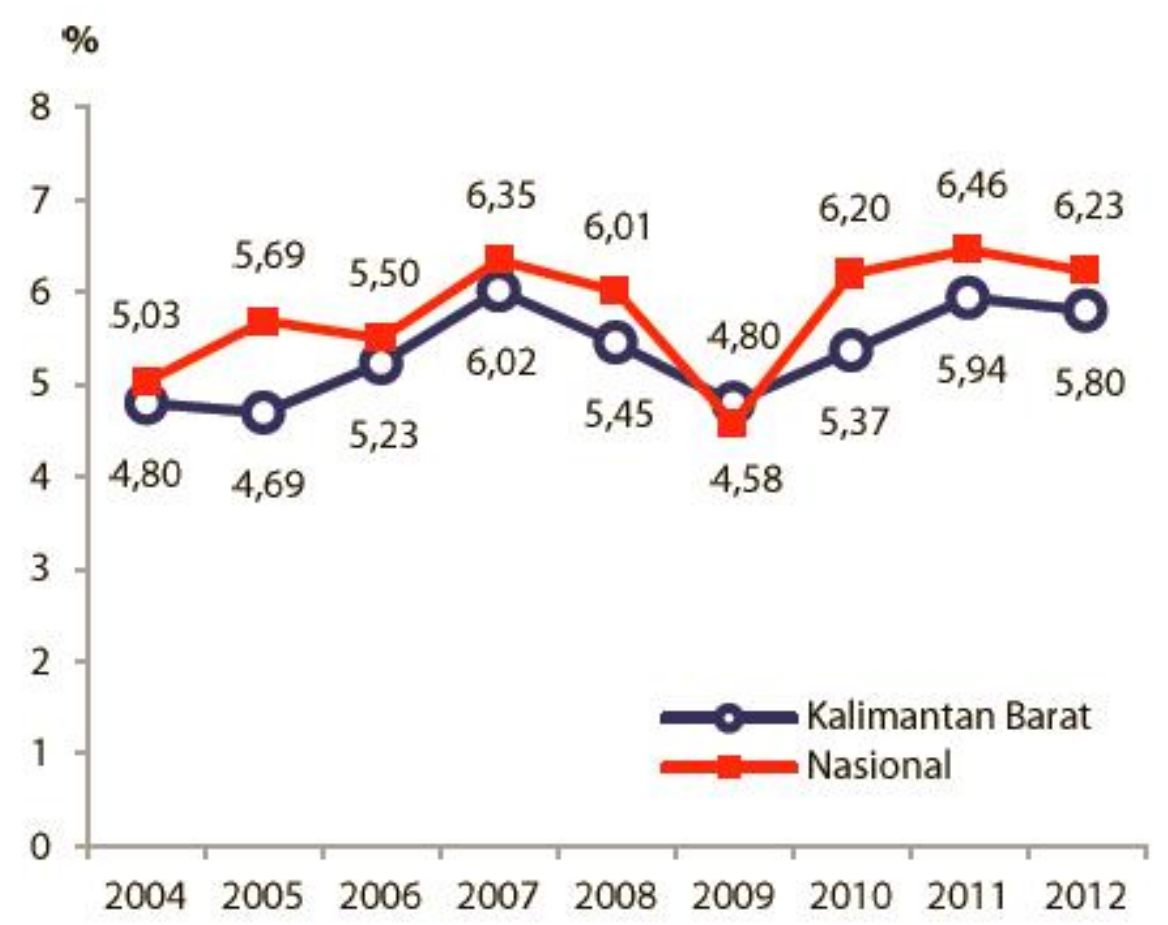

\section{Grafik 1.Pertumbuhan Ekonomi Provinsi Kalimantan Barat Terhadap Nasional Tahun 2004-2012 (\%)}

Sumber: Buku Data dan Informasi Kinerja Pembangunan 2004-2012

Pada tahun 2009 terjadi trend menurun baik pada tingkat pertumbuhan ekonomi Provinsi Kalimantan Barat maupun pada tingkat pertumbhunan ekonomi Nasional, namun ketika pertumbuhan ekonomi nasional menukik tajam pertumbuhan ekonomi Provinsi Kalimantan Barat mengalami penurunan yang relative moderat, dimana tingkat pertumbuhan ekonomi nasional turun sebanyak 1,52\% dari 6,01\% menjadi 4,58\%. Sebaliknya penurunan tingkat pertumbuhan ekonomi Provinsi Kalimantan Barat hanya sebesar $0,65 \%$ dari $5,45 \%$ menjadi $4,80 \%$. Jadi, terdapat perbedaan tingkat pertumbuhan ekonomi sebesar $1,52 \%-0,65 \%=0,87 \%$. Adalah sangat menarik untuk dikaji bahwa krisis financial di tingkat internasional memiliki dampak yang berbeda terhadap perekonomian nasional dan Kalimantan Barat dimana perekonomian nasional mengalami konjungtur yang drastis seperti itu. Kondisi ini menunjukkan perekonomian Kalimantan Barat tidak sepenuhnya tergantung pada kondisi ekonomi nasional/internasional. Hal ini tergambar pula dari struktur perekonomian Kalimantan Barat yang berbeda dengan struktur perekonomian di tingkat nasional yang didominasi sector industry. Sebagaimana diketahui struktur perekonomian Kalimantan Barat didominasi oleh secara bersama-sama oleh sector pertanian dan sektor industri.

Pada tahun 2010 pertumbuhan ekonomi Provinsi Kalimantan Barat kembali tertinggal dari tingkat pertumbuhan ekonomi nasional meskipun pada tahun 2012 perbedaannya kembali mengecil, yaitu sebesar $0,43 \%$. Adalah menarik untuk diteliti 
bagaimana mekanisme dan proses ekonomi yang berlaku selama periode 9 tahun tersebut sehingga menghasilkan pola pertumbuhan ekonomi nasional dan daerah yang berubahubah mulai dari pola divergensi, convergensi, dan parallel. Namun demikian secara umum perekonomian Kalimantan Barat dapat dikatakan mengalami kemajuan dibanding dilihat dari produksi barang dan jasa yang dihasilkan antar waktu.

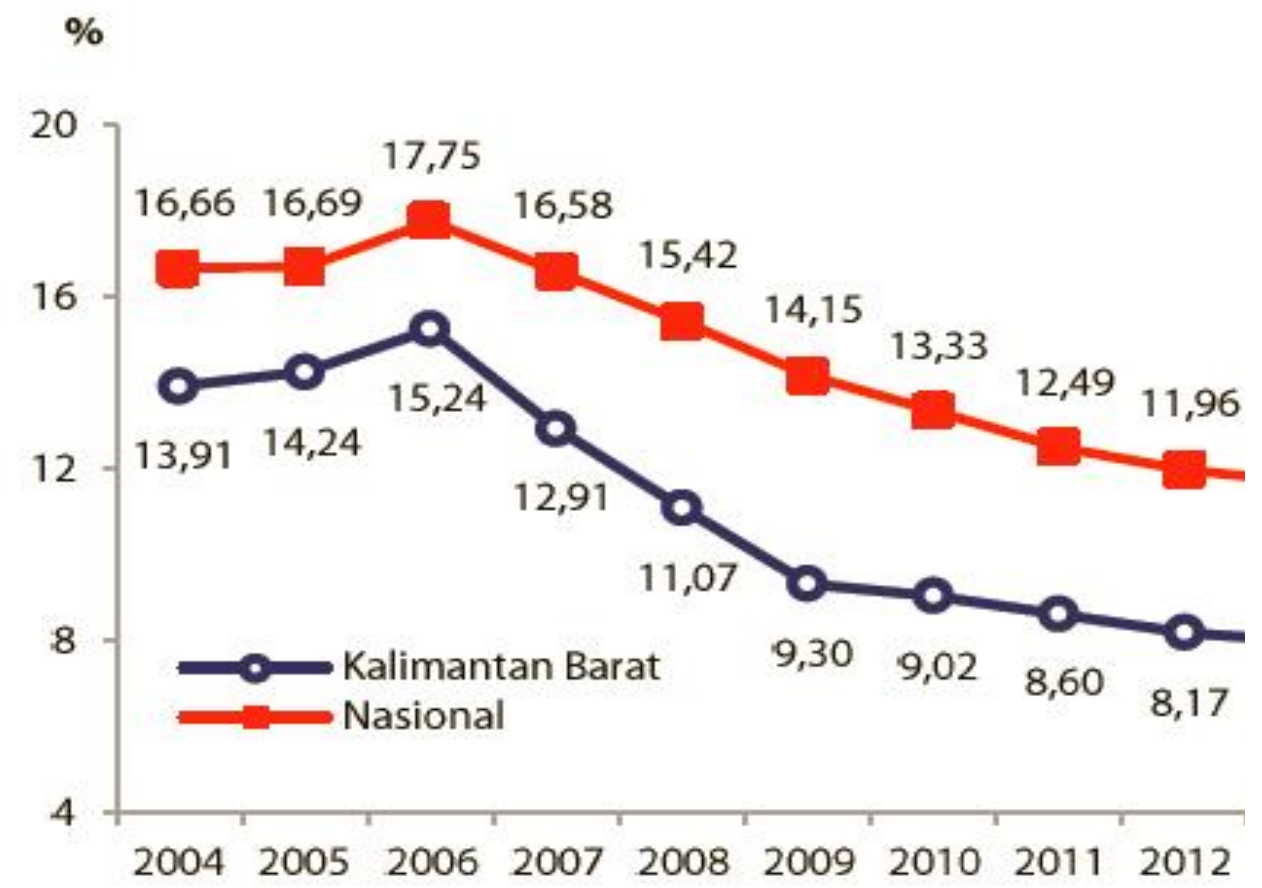

Grafik 2.Kemiskinan Di Kalimantan Barat Terhadap Nasional Tahun 2004-2012 (\%)

Sumber: Buku Data dan Informasi Kinerja Pembangunan 2004-2012

Gambar 2 menunjukkan permasalahan kemiskinan yang masih dihadapi dalam pembangunan ekonomi dan manusia di Kalimantan Barat.Gambaran mengenai tingkat kemiskinan yang berlaku di Propinsi Kalimantan Barat memperlihatkan tendensi yang parallel dengan perkembangan tingkat kemiskinan masyarakat secara Nasional. Data ini menunjukkan bahwa angka kemiskinan tertinggi terdapat pada periode Tahun 2006 yaitu 17,75\% untuk tingkat Nasional dan 15,24\% untuk Propinsi Kalimantan Barat. Tingkat kemiskinan terendah terdapat pada tahun 2012 yaitu 11,96 untuk tingkat Nasional dan 8,17 untuk Propinsi Kalimantan Barat.

Pada tahun 2004 tingkat kemiskinan propinsi Kalimantan Barat berada 2,75\% lebih rendah dari tingkat kemiskinan nasional, sedangkan pada tahun 2013 perbedaan tersebut menjadi lebih besar yaitu 3,79\%. Nampaknya perbedaan ini cukup positif bagi perkembangan tingkat kesejahteraan masyarakat Kalimantan Barat. Tetapi kita tetap harus berhati-hati dalam menarik kesimpulan tersebut, untuk mengantisipasi data yang bias serta indikator dan definisi kemiskinan yang masih mengundang perdebatan. Namun demikian secara umum, kemiskinan Kalimantan Barat mengalami penurunan yang 
signifikan antar waktu yang menunjukkan prestasi Kalimantan Barat dalam memajukan daerahnya.

Jika dilihat dari dari luas wilayah Provinsi Kalimantan Barat merupakan provinsi ke-4 terbesar di Indonesia. Dengan luasan mencapai 146.000 km persegi. Kalimantan Barat terbagi menjadi 14 Kabupaten dan Kota yang dapat dikategorikan menjadi kawasan pesisir, kawasan pedalaman, kawasan perbatasan dan kawasan perkotaan.

Keragaman karakteristik dan pola implementasi desentralisasi melalui UndangUndang No 22 Tahun 1999 tentang Pemerintahan Daerah, kemudian diganti dengan Undang-Undang No 32 Tahun 2004 yang mengamanatkan daerah untuk menentukan nasibnya sendiri. Adanya kebebasan untuk menentukan nasib sendiri tersebut mengakibatkan pencapaian indikator fundamental ekonomi daerah yang berbeda-beda pula. Lebih lanjut Undang-Undang No 25 Tahun 1999 tentang Perimbangan Keuangan antara Pemerintah Pusat dan Daerah juga diganti dengan Undang-Undang No 33 Tahun 2004. Dengan demikian maka gambaran mengenai ekonomi Kalimantan Barat sebagaimana diuraikan di atas terasa masih belum memadai. Perbedaan letak geografis daerah dapat memiliki dampak terhadap struktur ekonomi daerah yang bersangkutan. Untuk itu perlu diidentifikasi profil dan klasifikasi masing-masing kabupaten dan kota yang ada di Kalimantan Barat berdasarkan indikator fundamental ekonomi daerah.

Berdasarkan latar belakang penilitian, permasalahan dalam penelitian ini diarahkan pada upaya mengidentifikasi profil dan klasifikasi pemerintah kabupaten dan kota yang ada di Kalimantan Barat berdasarkan indikator fundamental ekonomi daerah yang meliputi pertumbuhan ekonomi, pendapatan perkapita dan Indeks Pembangunan Manusia (IPM). Informasi tentang profil dan karakteristiks daerah merupakan masukan yang sangat penting bagi formulasi kebijakan serta upaya merencanakan dan melaksanakan pembangunan daerah.Penelitian ini berutujuan untuk mengidentifikasi profil dan klasifikasi kabupaten dan kota yang ada di Kalimantan Barat berdasarkan indikator fundamental ekonomi daerah.

\section{TINJAUAN PUSTAKA}

Pembangunan daerah selalu menghadapi tantangan disebabkan berbagai faktor ekonomi maupun non ekonomi yang secara langsung maupun tidak langsung mempengaruhi upaya pembangunan tersebut. Pada awalnya pembangunan diidentikkan dengan pertumbuhan ekonomi. Oleh karena itu upaya pembangunan ekonomi diarahkan pada upaya untuk memacu pertumbuhan ekonomi sehingga memunculkan teori-teori pertumbuhan klasik, neoklasik maupun teori pertumbuhan baru/teori pertumbuhan endogen (Todaro \& Smith 2012).

Teori-teori pertumbuhan ekonomi yang diperkenalkan oleh para ekonom menemukan bahwa mesin pertumbuhan ekonomi di negara berkembang maupun negara maju bergerak di atas empat roda/faktor pertumbuhan ekonomi yaitu sumberdaya alam, 
sumberdaya manusia, pembentukan capital dan teknologi (Samuelson, 1995). Hal ini sesuai dengan teori pertumbuhan ekonomi Neo Klasik yang menyimpulkan bahwa laju tingkat pertumbuhan ekonomi yang dapat dicapai suatu negara tergantung kepada tingkat perkembangan teknologi, peranan modal dan peranan tenaga kerja dalam menciptakan pendapatan negara (Sukirno, 1985).

Perbedaan mendasar antara negara berkembang dan negara maju terletak pada akumulasi modal yang bersumber dari sisa pendapatan yang tidak dikonsumsi. Hal ini terkait dengan rendahnya pendapatan di negara berkembang sehingga aliran capital dari luar negeri baik yang berasal dari investasi asing maupun hutang luar negeri menjadi salah satu sumber akumulasi capital yang penting. Kebanyakan negara berkembang hanya mempunyai tabungan dan investasi sebesar $2 \%$ sampai $6 \%$ dari pendapatan nasionalnya, sedangkan tabungan dan investasi negara maju selama periode pertumbuhan yang cepat mencapai $10 \%$ sampai $20 \%$ dari pendapatan nasionalnya (Irawan dan Suparmoko, 1992).

Akan halnya tenaga kerja, Batiz \& Batiz (1994) menyatakan bahwa seringkali teknologi dan capital telah tersedia dalam jumlah yang relative tetap, sehingga jumlah output yang dihasilkan dalam suatu perekonomian sangat tergantung pada tenaga kerja. Penduduk sebagai sumber tenaga kerja memiliki fungsi ganda dalam perekonomian, yaitu sebagai konsumen/pasar apabila dilihat dari sisi permintaan serta tenaga kerja atau produsen apabila dilihat dari sisi penawaran.

Sebagaimana dikatakan Anderson (1991), "The concept of economic growth was rooted from the larger concept of 'progress'. The concept of progress can be traced back historically through different paths i.e. religion, civilization and development of system of thought. The latter can be seen from the development of economics by Adam Smith in 1776 that was mainly concern with economic advance."

Akumulasi sumberdaya dalam jangka panjang akan meningkatkan penawaran faktor produksi dan pada gilirannya akan meningkatkan produksi barang dan jasa (pertumbuhan ekonomi). Karena itu upaya pembangunan lebih diarahkan pada upaya pemupukan modal dan industrialisasi modern. Seiring dengan perkembangan waktu, awal dekade 1970an terjadi redefinisi makna pembangunan disebabkan masalah-masalah seperti kemiskinan, ketimpangan distribusi pendapatan, dominasi struktural serta pengangguran yang tidak teratasi melalui pertumbuhan ekonomi. Menyadari bahwa pertumbuhan ekonomi merupakan kondisi yang perlu namun bukan kondisi cukup bagi pembangunan, paradigma pembangunan selanjutnya mengalami pergeseran ke arah strategi pembangunan dengan pemerataan/distribusi pendapatan, strategi pembangunan dengan pemenuhan kebutuhan pokok (basic needs), strategi pembangunan mandiri, strategi pembangunan berkelanjutan (sustainable development) serta strategi pembangunan berdimensi etnik/ethnodevelopment (Kuncoro, 2004). 
Strategi pembangunan menurut pandangan Klasik mengandalkan peran sisi penawaran dalam mencapai tingkat kegiatan ekonomi yang lebih tinggi. Bagaimanapun kemandegan ekonomi sejak masa depresi besar telah memposisikan pemerintah sebagai pemain penting melalui kemampuannya menciptakan permintaan dalam ekonomi (pandangan Keynesian). Pandangan Keynesian mengenai perekonomian yang disetir oleh permintaan agregat telah memberikan justifikasi campur tangan pemerintah dalam menciptakan permintaan dalam perekonomian. Pemerintah melalui efek pengganda dapat meningkatkan kegiatan produktif dalam perekonomian melalui pengaturan pengeluaran pemerintah. Pembangunan ekonomi menurut pandangan Keynesian ditentukan oleh kegiatan rumah tangga, perusahaan, pemerintah dan luar negeri dalam membentuk permintaan agregat (aggregate demand).

Keberhasilan pembangunan tersebut bagaimanapun perlu diukur dengan menggunakan indikator baik sosial maupun ekonomi yang dapat diterima secara umum serta mampu mendeskripsikan kondisi riil di lapangan. Indikator yang umum digunakan untuk mengevaluasi keberhasilan pembangunan ekonomi adalah angka-angka PDRB, pendapatan perkapita, pertumbuhan ekonomi, ketenagakerjaan, kemiskinan, dan kondisi sosial kemasyakaratan di bidang pendidikan dan kesehatan.

Meskipun pendapatan masih merupakan indikator yang paling banyak digunakan sebagai ukuran pertumbuhan output (Frumkin, 1990), validitas indikator konvensional ini masih diperdebatkan. Perdebatan yang terjadi berkaitan dengan bagaimana keterkaitan kemajuan ekonomi ini dengan kemajuan yang lebih luas dalam hal moral, kemanusiaan dan sosial. Ini disebabkan pertumbuhan ekonomi yang tinggi biasanya diciptakan dengan biaya lingkungan dan kemanusiaan yang tinggi (Froyen, 1996). Untuk itu badan-badan dunia seperti PBB dan Bank Dunia memperkenalkan indikator-indikator tambahan selain indikator ekonomi. indikator sosial yang biasanya digunakan berkaitan dengan pendidikan, kesehatan serta lingkungan.

Salah satu indikator penting yang dianggap lebih holistic dari sekedar pertumbuhan ekonomi adalah Human Development Index (Indeks Pembangunan Manusia). HDI merupakan indeks gabungan dari tiga indikator: longevity sebagai ukuran harapan hidup, pengetahuan (knowledge) yang diukur dengan kombinasi melek huruf penduduk dewasa (bobot $3 / 4$ ) dan gabungan dari rasio pendidikan tinggi primer, sekunder, tersier bruto (bobot 1/3) dan standar hidup layak (decent standard of living) yang diukur oleh PDB riil per kapita dalam paritas daya beli (lihat Kuncoro, 2004). Ukuran ini digunakan untuk melengkapi indikator pembangunan yang lama seperti indikator social ekonomi dari Irma-Adelman, Physical Quality Life Index dll (Todaro \& Smith 2012).

Sebagaimana dapat dilihat dalam Kuncoro (2004), Indeks 3 komponen IPM dihitung dengan rumus berikut:

$$
\text { Indeks } X(i)=[X(i)-X(i) \min ] /[X(i) \text { maks }-X(i) \text { min }] \text {. }
$$


Dimana:

$\mathrm{X}(\mathrm{i})=$ indikator ke-I $(\mathrm{i}=1,2,3)$

$\mathrm{X}$ (i) maks $=$ nilai maksimum $\mathrm{X}$ (i)

$\mathrm{X}$ (i) $\min =$ nilai minimum $\mathrm{X}$ (i)

Kisaran antara nilai minimum dan nilai maksimum untuk indikator HDI adalah:

$\begin{array}{ll}\text { Harapan hidup waktu kelahiran } & : 25-85 \text { (standar UNDP) } \\ \text { Tingkat melek huruf } & : 0-100 \text { (standar UNDP) } \\ \text { Rata-rata lama sekolah } & : 0-15 \text { (standar UNDP) }\end{array}$

Konsumsi perkapita yang disesuaikan : 300.000-732.720

Berdasarkan prosedur di atas, berikut adalah rumus HDI:

$$
\mathrm{HDI}=1 / 3\left[\mathrm{X}_{(1)}+\mathrm{X}_{(2)}+\mathrm{X}_{(3)}\right]
$$

Dimana:

$\mathrm{X}_{(1)}=$ indeks harapan hidup waktu lahir

$X_{(2)}=$ indeks pendidikan $=2 / 3$ indeks melek huruf $+1 / 3$ indeks rata-rata lama sekolah

$\mathrm{X}_{(3)}=$ indeks standar hidup layak/paritas daya beli

\section{METODE PENELITIAN}

\subsection{Metode Pengumpulan Data dan Lokasi Penelitian}

Dalam rangka mencapai tujuan penelitian, penelitian ini mengandalkan data sekunder. Data sekunder diperoleh dari BPS Kalimantan Barat serta instansi terkait lainnya. Data dimaksud berupa publikasi statistik serta dokumen lain yang relevan. Data Pertumbuhan ekonomi, pendapatan perkapita dan HDI yang digunakan adalah tahun 2005 sampai dengan tahun 2011, oleh karena itu Kabupaten Kubu Raya tidak dianalisis karena baru terbentuk pada tahun 2007. Untuk menjawab tujuan pertama, data sekunder dimaksud digunakan untuk mengidentifikasi dan mengklasifikasikan kabupaten dan kota di Kalimantan Barat berdasarkan pertumbuhan ekonomi dan pendapatan perkapita. Sedangkan untuk tujuan kedua dan ketiga data tersebut digunakan untuk mengidentifikasi dan mengklasifikasikan kabupaten dan kota di Kalimantan Barat berdasarkan HDI dan pendapatan perkapita serta HDI dan pertumbuhan ekonomi.

Lokasi penelitian adalah Kalimantan Barat yang dibagi menjadi 13 kabupaten kota yaitu Kota Pontianak, Kota Singkawang, Kabupaten Sambas, Kabupaten Pontianak, Kabupaten Landak, Kabupaten Ketapang, Kabupaten Kayong Utara, Kabupaten Sanggau, Kabupaten Kapuas Hulu, Kabupaten Bengkayang, Kabupaten Sekadau, Kabupaten Melawi, dan Kabupaten Sintang. 


\subsection{Metode Analisis}

Dalam pengolahan data sekunder untuk menjawab tujuan pertama, penelitian ini menggunakan alat analisis tipologi daerah untuk mengetahui pola dan struktur pertumbuhan ekonomi masing-masing daerah (Kuncoro, 2004). Tipologi daerah membagi daerah menjadi empat kategori, yaitu (1) daerah yang berpendapatan tinggi dan pertumbuhan ekonomi tinggi; (2) daerah yang berpendapatan tinggi dan pertumbuhan ekonomi rendah; (3) daerah yang berpendapatan rendah dan pertumbuhan ekonomi tinggi; serta (4) daerah yang berpendapatan rendah dan pertumbuhan ekonomi rendah. Lebih jelasnya klasifikasi tersebut dapat dilihat pada Tabel 1.

Tabel 1. Tipologi Daerah Pendapatan Perkapita Dan Pertumbuhan Ekonomi

\begin{tabular}{cll}
\hline $\begin{array}{c}\text { Pertumbuhan } \\
\text { Ekonomi }\end{array}$ & \multicolumn{1}{c}{ PDRB per kapita } \\
\cline { 2 - 3 }$(\mathbf{r i}>\mathbf{r})$ & \multicolumn{1}{c}{$\mathbf{c}$} & \multicolumn{1}{c}{$(\mathbf{y i}>\mathbf{y})$} \\
& $\begin{array}{l}\text { Pendapatan tinggi \& pertumbuhan } \\
\text { tinggi }\end{array}$ & $\begin{array}{l}\text { Pendapatan rendah dan pertumbuhan } \\
\text { tinggi }\end{array}$ \\
(ri<r) & $\begin{array}{l}\text { Pendapatan tinggi dan pertumbuhan } \\
\text { rendah }\end{array}$ & $\begin{array}{l}\text { Pendapatan rendah dan pertumbuhan } \\
\text { rendah }\end{array}$ \\
\hline
\end{tabular}

Keterangan:

$\mathrm{r}$ : rata-rata pertumbuhan ekonomi kabupaten/kota

y : rata-rata PDRB per kapita kabupaten/kota

ri : pertumbuhan ekonomi kabupaten/kota yang diamati (i)

yi : PDRB per kapita kabupaten/kota yang diamati (i)

Dalam pengolahan data sekunder untuk menjawab tujuan kedua, penelitian ini menggunakan alat analisis tipologi daerah dengan membagi daerah menjadi empat kategori yaitu (1) daerah yang berpendapatan tinggi dan pembangunan manusia yang tinggi; (2) daerah yang berpendapatan tinggi dan pembangunan manusia yang rendah; (3) daerah yang berpendapatan rendah dan pembangunan manusia yang tinggi; serta (4) daerah yang berpendapatan rendah dan pembangunan manusia yang rendah (Tabel 2.)

Tabel 2. Tipologi Daerah Pendapatan Perkapita dan HDI

\begin{tabular}{cll}
\hline HDI & \multicolumn{1}{c}{ PDRB per kapita } \\
\cline { 2 - 3 }$(\mathbf{r i}>\mathbf{r})$ & \multicolumn{1}{c}{$(\mathbf{y i}>\mathbf{y})$} & \multicolumn{1}{c}{$(\mathbf{y i}<\mathbf{y})$} \\
\hline \multirow{2}{*}{$(\mathbf{r}<\mathbf{r})$} & $\begin{array}{l}\text { Pendapatan tinggi \& pertumbuhan tinggi } \\
\text { Pendapatan tinggi dan pertumbuhan }\end{array}$ & $\begin{array}{l}\text { Pendapata rendah dan pertumbuhan } \\
\text { tinggi } \\
\text { Pendapatan rendah dan pertumbuhan } \\
\text { rendah }\end{array}$ \\
\hline
\end{tabular}

Keterangan:

$\mathrm{r}$ : rata-rata HDI kabupaten/kota

y : rata-rata PDRB per kapita kabupaten/kota

ri : HDI kabupaten/kota yang diamati (i)

yi : PDRB per kapita kabupaten/kota yang diamati (i) 
Dalam pengolahan data sekunder untuk menjawab tujuan ketiga, penelitian ini menggunakan alat analisis tipologi daerah dengan membagi daerah menjadi empat kategori yaitu (1) daerah yang memiliki pertumbuhan ekonomi tinggi dan pembangunan manusia yang tinggi; (2) daerah yang memiliki pertumbuhan ekonomi tinggi dan pembangunan manusia yang rendah; (3) daerah yang memiliki pertumbuhan ekonomi rendah dan pembangunan manusia yang tinggi; serta (4) daerah yang memiliki pertumbuhan ekonomi rendah dan pembangunan manusia yang rendah (Tabel 3).

Tabel 3. Tipologi Daerah Pendapatan Perkapita dan Pertumbuhan Ekonomi dan HDI

\begin{tabular}{|c|c|c|}
\hline \multirow[t]{2}{*}{ PertumbuhanEkonomi } & \multicolumn{2}{|c|}{ HDI } \\
\hline & $(\mathbf{y i}>\mathbf{y})$ & $(\mathbf{y i}<\mathbf{y})$ \\
\hline$(\mathbf{r i}>\mathbf{r})$ & Pendapatan tinggi \& pertumbuhan tinggi & $\begin{array}{l}\text { Pendapata rendah dan } \\
\text { pertumbuhan tinggi }\end{array}$ \\
\hline$(\mathbf{r i}<\mathbf{r})$ & $\begin{array}{l}\text { Pendapatan tinggi dan pertumbuhan } \\
\text { rendah }\end{array}$ & $\begin{array}{l}\text { Pendapatan rendah dan } \\
\text { pertumbuhan rendah }\end{array}$ \\
\hline
\end{tabular}

Keterangan:

$r$ : rata-rata pertumbuhan ekonomi kabupaten/kota

y : rata-rata HDI kabupaten/kota

ri : pertumbuhan ekonomi kabupaten/kota yang diamati (i)

yi : HDI kabupaten/kota yang diamati (i)

Hasil dari ketiga kombinasi indikator ini dibandingkan untuk mendapatkan kabupaten/kota yang memiliki indikator yang konsisten atau tidak konsisten. Pemahaman mengenai kondisi pertumbuhan ekonomi yang dibandingkan dengan pendapatan perkapita serta kualitas sumberdaya manusia yang diukur dari HDI masing-masing kabupaten kota ini dianalisis untuk kemudian disimpulkan sebagai dasar rekomendasi kebijakan.

\subsection{Perbandingan Indikator Sosial Ekonomi Antar Kabupaten/Kota Di Kalimantan Barat}

Bab ini memberikan gambaran tentang kondisi social ekonomi pada kabupaten/kota yang terdapat di Kalimantan Barat. Dengan menampilkan data-data makro antar daerah, perbandingan pencapaian serta kondisi masing-masing daerah dapat dipahami secara komprehensif.

\subsubsection{Perkembangan Penduduk}

Jumlah penduduk Provinsi Kalimantan Barat terus meningkat. Dalam masa 4 tahun Sejak tahun 2007 sampai tahun 2011 penduduk bertambah sebanyak 4.477.384 $4.178 .498=298.886$ jiwa $(7,15 \%)$ atau rata-rata $1.79 \%$ setahun. Data ini menunjukkan bahwa laju pertumbuhan penduduk di provinsi ini lebih tinggi dari laju pertumbuhan penduduk Indonesia berdasarkan Sensus 2010 yang hanya mencapai 1,49\% setahun. Kendatipun laju pertumbuhannya lebih cepat dari laju pertumbuhan penduduk secara 
nasional, berkat territorialnya yang cukup luas kepadatannya tidak begitu mengkhawatirkan.

\subsubsection{Perkembangan Ketenagakerjaan}

Untuk menganalisis aspek ketenagakerjaan kita perlu mereview makna beberapa istilah yang dipergunakan dalam grafik ini. Penduduk yang dianggap produktif adalah yang sudah berusia 15 tahun ke atas. Penduduk dalam kategori ini terbagi menjadi 2 bagian yaitu Angkatan kerja dan Bukan Angkatan Kerja. Angkatan kerja adalah mereka yang bekerja dan yang berada dalam kondisi Pengangguran Terbuka.

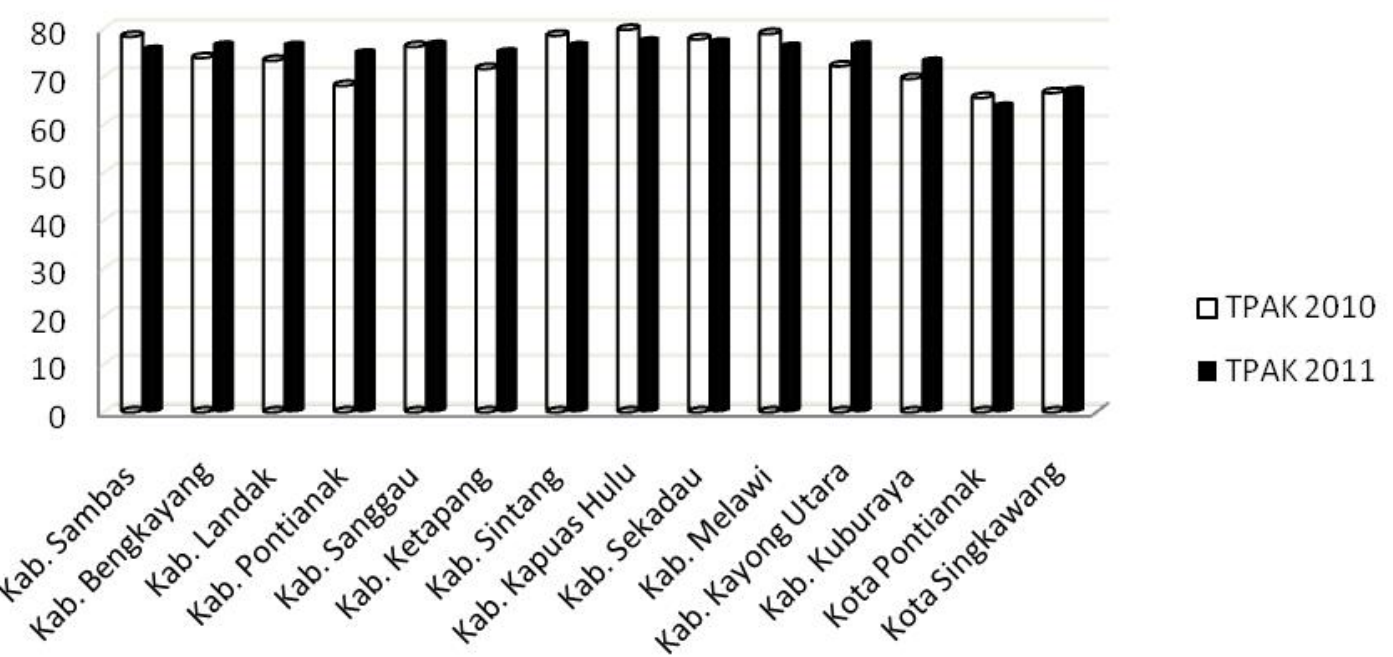

\section{Grafik 3.Tingkat Partisipasi Angkatan Kerja (TPAK) Kabupaten/Kota Di Kalbar}

Sumber: BPS, Survei Angkatan Kerja Nasional, 2011

Penduduk yang berada dalam kategori Pengangguran Terbuka terdiri atas mereka yang mencari kerja, mempersiapkan usaha, merasa tidak mungkin mendapatkan pekerjaan, dan mereka yang sudah mendapat pekerjaan tetapi belum dimulai bekerja. Penduduk berumur 15 tahun keatas yang Bukan Angkatan Kerja adalah mereka yang sekolah, mengurusi rumah tangga, dan lainnya. Angka-angka yang tercantum dalam sel grafik menunjukkan persentase. Dengan memahami beberapa pengertian tersebut, konten grafik dapat dibahas secara komprehensif seperti berikut ini.

Jika kita bandingkan TPAK tahun 2010 dan 2011 untuk tingkat provinsi terdapat peningkatan persentase TPAK sebesar $0.76 \%$, tetapi sebagian dari Kabupaten justru mengalami penurunan seperti Sambas, Sintang, Kapuas Hulu, Sekadau, Melawi, dan Kabupaten Pontianak. Kabupaten-Kabupaten yang mengalami penurunan TPAK perlu mencari tahu mengapa hal itu terjadi? Karena penurunan TPAK berarti peningkatan beban masyarakat secara keseluruhan. Ketika hal itu terjadi pada 6 dari 14 wilayah kita perlu memberikan perhatian yang serius. Dalam Pengangguran Terbuka penurunan berarti positif dan peningkatan berarti negatif. Peningkatan TPT terjadi di Kabupaten 
Bengkayang, Sintang, Kapuas Hulu, Sekadau, dan Melawi. Yang mengalami penurunan TPT adalah Kabupaten Sambas, Landak, Pontianak, Sanggau, Ketapang, Kayong Utara, Kubu Raaya, Kota Pontianak, dan Kota Singkawang. Secara keseluruhan Provinsi Kalimantan Barat juuga mengalami penurunan TPT pada tahun 2011. Daerah-daerah yang mengalami peningkatan TPT patut menjadi risau karena pwngangguran juga berarti bertambahnya beban masyarakat secara keseluruhan.

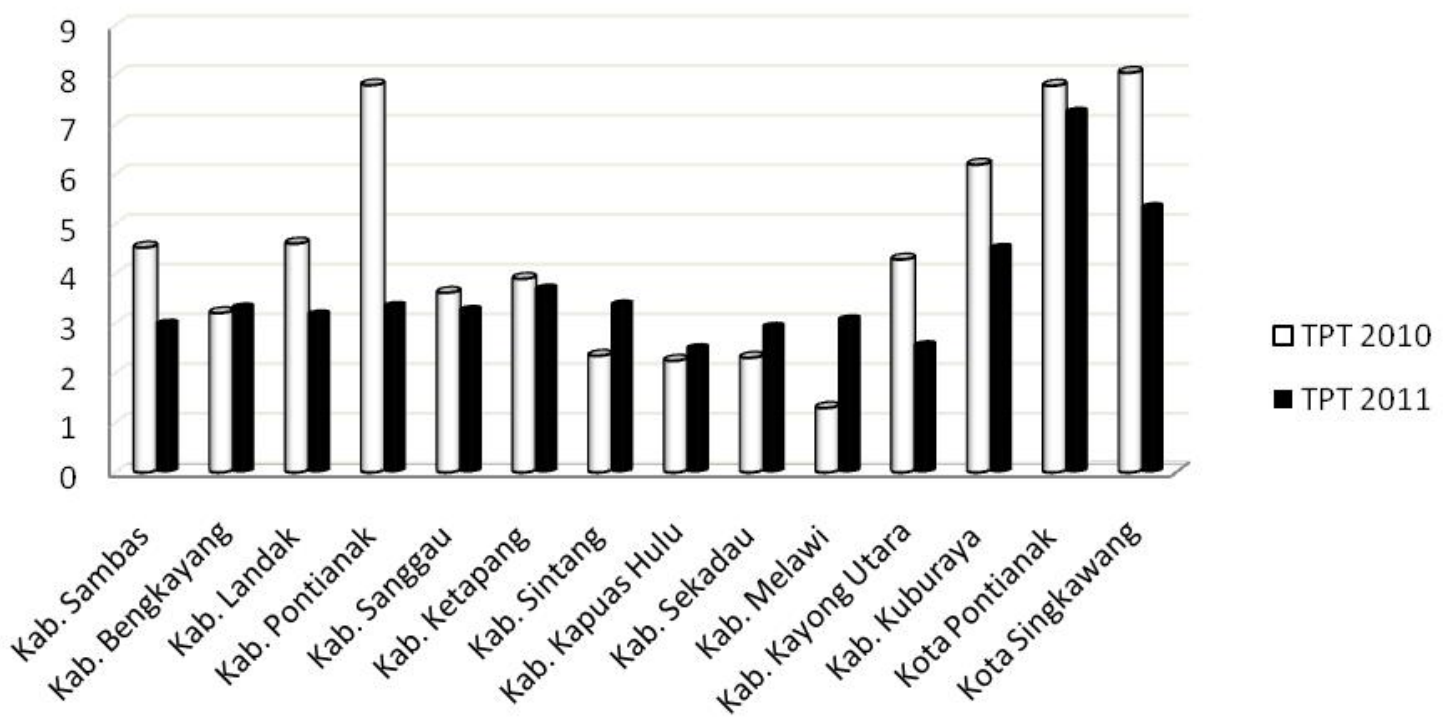

\section{Grafik 4. Tingkat Pengangguran TerbukaKabupaten/Kota Di Kalimantan Barat}

Sumber: BPS, Survei Angkatan Kerja Nasional 2011

\subsubsection{Pertumbuhan Ekonomi}

Pertumbuhan ekonomi diartikan sebagai perkembangan kegiatan dalam perekonomian yang mengakibatkan peningkatan produksi barang dan jasa dalam masyarakat dan peningkatan kemakmuran masyarakat.

Provinsi Kalimantan Barat mengalami laju pertumbuhan tertinggi pada tahun 2007 yaitu sebesar $6.02 \%$ dengan peningkatan sebesar 0,79\% dari tahun 2006. Bagi provinsi ini moment kedua yang perlu diwaspadai adalah laju pertumbuhan ekonomi yang terendah yang terjadi pada tahun 2009 yaitu sebesar 4,76\%. Perlambatan ekonomi global pada 2008-2009 pada gilirannya mempengaruhi pula perekonomian Kalimantan Barat.

Data yang tersedia dari BPS Kalbar memperlihatkan adanya beberapa pola pertumbuhan ekonomi selama periode 3 tahun dari tahun 2008-2010 sebagai berikut. Pertama, Pola terus meningkat (-++) yang meliputi Sektor Bangunan, Sektor Jasa-Jasa, dan Sektor Keuangan, Persewaan dan Jasa Perusahaan. Kedua, Pola penurunan dan kembali meningkat (+-+) yang meliputi Sektor Pertambangan dan Penggalian, Sektor 
Industri Pengolahan, Listrik Gas dan air bersih, Sektor Perdagangan Hotel dan Restoran, dan PDRB. Ketiga, Pola terus menurun (+--) yang diperlihatkan oleh Sektor Pertanian.

Diantara ketiga pola ini yang paling menguntungkan adalah pola yang pertama, karena pola ini memperlihatkan steady growth yang memang menjadi tujuan pembangunan ekonomi. Pilihan yang kedua adalah penurunan yang diikuti oleh peningkatan. Trend yang kedua ini mengindikasikan bahwa upaya menanggulangi kemunduran berhasil dilakukan. Pola yang ketiga adalah yang sangat merugikan karena disini terjadi trend negatif yang berkepanjangan. Dengan ditemukannya ketiga pola petumbuhan tersebut pemerintah dapat merancang kebijakan ekonomi yang tepat dalam memelihara trend yang baik dan menanggulangi trend yang terindikasi negatif.

\subsubsection{Pendapatan Perkapita}

Banyak orang beranggapan bahwa pendapatan perkapita tidak dapat menjelaskan keadaan yang sebenarnya dari tingkat kesejahteraan penduduk, karena dalam kenyataannya pendapatan terbesar hanya dinikmati oleh sebagian kecil penduduk, sedangkan bagian terbesar penduduk hanya menerima penghasilan yang sangat kecil. Ketika pendapatan perkapita dihitung berdasarkan jumlah pendapatan dibagi dengan jumlah penduduk, diperoleh angka rata-rata pendapatan yang lebih tinggi dibandingkan pendapatan sebenarnya penduduk berpenghasilan rendah. Namun pendapatan perkapita dapat membantu kita dalam upaya membandingkan pendapatan antar wilayah dalam satu negara dan pendapatan antar negara.

Produk Domestik Regional Bruto adalah akumulasi pendapatan sektor-sektor kegiatan ekonomi masyarakat yang terdiri atas 9 sektor yaitu: pertanian, pertambangan dan penggalian, industri pengolahan, listrik gas dan air bersih, bangunan, perdagangan hotel dan restoran, pengangkutan dan komunikasi, keuangan persewaan dan jasa perusahaan, dan jasa-jasa. Perhitungan PDRB dihitung per Kabupaten dan Kota untuk setiap Tahun Anggaran. PDRB perkapita diperoleh dengan membagi nilai PDRB dengan jumlah penduduk suatu region atau Kabupaten/Kota.

Berdasarkan data Kalbar yang tersedia, kita dapat menarik beberapa kesimpulan sebagai berikut. Pertama, PDRB perkapita tertinggi diperoleh oleh Kota Pontianak yaitu diatas 10 juta per tahun. Kedua, PDRB perkapita terendah diperoleh oleh Kabupaten Melawi yaitu dibawah 4 juta per tahun. Ketiga, Selama Periode 2007-2010, 12 Kabupaten/Kota mengalami peningkatan nilai PDRB perkapita setiap Tahun, yaitu Kab Sambas, Kab Bengkayang, Kab Landak, Kab Pontianak, Kab Sanggau, Kab Sintang, Kab Kapuas Hulu, Kab Sekadau, Kab Melawi, Kab Kayong Utara, Kab Kubu Raya, dan Kota Singkawang. Keempat, Kabupaten Ketapang dan Kota Pontianak mengalami penurunan PDRB perkapita pada tahun 2009.

Jika 14 Kabupaten dan Kota di Provinsi Kalimantan Barat kita pilah berdasarkan besarnya PDRB perkapita masing-masing, kita akan memperoleh gambaran sebagai berikut. Kelompok pertama yang meliputi Kabupaten dan Kota dengan PDRB perkapita 
2.500.000-5000.000, yaitu Kabupaten Kapuas Hulu, Kabupaten Bengkayang, Kabupaten Landak, Kabupaten Kayong Utara, Kabupaten Sekadau dan Kabupaten Melawi. Kelompok kedua dengan PDRB perkapita >5000.000-7.500.000, yaitu Kabupaten Ketapang, Kabupaten Sanggau, Kota Singkawang, Kabupaten Sambas dan Kabupaten Sintang. Kelompok ketiga dengan PDRB perkapita >7.500.000-10.000.000, yaitu Kabupaten Pontianak dan Kabupaten Kubu Raya. Kelompok terakhir dengan PDRB perkapita >10.000.000-12.500.000, yaitu Kota Pontianak.

\subsubsection{Pendidikan}

Data yang tersedia memperlihatkan pertumbuhan sekolah dasar pada 14 wilayah sejak tahun 2007-2011. Pada tahun 2007 data untuk Kabupaten Kayong Utara dan Kabupaten Kubu Raya masih bergabung dengan Kabupaten Induk masing-masing yitu Kabupaten Ketapang dan Kabupaten Pontianak. Terlihat pada tahun 2009 terjadi penurunan jumlah SD dari tahun sebelumnya sebanyak 13 buah. Jika data ini dapat diyakini kebenarannya, ini merupakan indikasi bahwa ada sekolah dasar yang sudah ada kemudian menghilang. Dalam kenyataannya kasus-kasus seperti itu memang terjadi terutama di daerah terpencil. Ada sekolah ditutup karena kekurangan murid, ada pula karena gurunya tidak bisa bertahan disebabkan berbagai alasan seperti alasan ekonomi, alasan keluarga, dan alasan kesehatan.

Pertumbuhan jumlah sekolah menengah pertama di Kalimantan Barat memperlihatkan jumlah yang menurun di sejumlah wilayah, misalnya tahun 2009 di Kabupaten Sambas, tahun 2011 di Kabupaten Landak, tahun 2008 di Kabupaten Sekadau, tahun 2012 di Kabupaten Kayong Utara, tahun 2008 di Kota Pontianak, dan tahun 2010 dan 2011 di Kota Singkawang. Pada tingkat SMP persaingan antar sekolah semakin gencar, sekolah-sekolah yang kurang bermutu akannkesulitan memperoleh murid baru, sehingga ada diantaranya yang terpaksa mengakhiri kegiatannya.

Jumlah SMU juga berkembang secara dinamis dalam periode 2007-2011. Sebagian besar wilayah mengalami peningkatan jumlah SMU, meskipun di antaranya ada yang mengalami penurunan pada tahun-tahun tertentu, misanya penurunan yang terjadi di Kabupaten Sambas tahun 1010, di Kabupaten Landak tahun 2011, Kabupaten Pontianak tahun 2011, Kabupaten Sanggau tahun 2011, Kabupaten Ketapang tahun 2010, Kabupaten Sintang tahun 2010, Kabupaten Kapuas Hulu tahun 2008, Kabupaten Melawi tahun 2009 dan 2011, Kota Pontianak tahun 2008, dan Kota Singkawang tahun 2009 dan 2010. Alasan menurunnya jumlah SMU di tempat-tempat tersebut sangat bervariasi, sehingga agak sulit untuk digeneralisir.

Ratio jumlah penduduk terhadap jumlahSD di Provinsi Kalimantan Barat dari tahun 2007 s/d 2011 adalah sebagai berikut: (1) 1 SD untuk 1074 penduduk, (2) 1 SMP untuk 4138 penduduk, (3) 1 SMU untuk 8972 penduduk. Pertumbuhan dari tahun ke tahun jumlah lembaga-lembaga pendidikan tersebut tidak menunjukkan peningkatan yang menyolok, bahkan diantaranya ada yang mengalami penurunan. 
Tabel 4. Rasio Jumlah Penduduk Terhadap Lembaga Pendidikan

\begin{tabular}{cccccccc}
\hline Tahun & $\begin{array}{c}\text { Jumlah } \\
\text { Penduduk }\end{array}$ & $\begin{array}{c}\text { Jumlah } \\
\text { SD }\end{array}$ & $\begin{array}{c}\text { Jumlah } \\
\text { SMP }\end{array}$ & $\begin{array}{c}\text { Jumlah } \\
\text { SMU }\end{array}$ & Ratio 2/3 & Ratio 2/4 & Ratio 2/5 \\
\hline $\mathbf{1}$ & $\mathbf{2}$ & $\mathbf{3}$ & $\mathbf{4}$ & $\mathbf{5}$ & $\mathbf{6}$ & $\mathbf{7}$ & $\mathbf{8}$ \\
\hline 2007 & 4.178 .498 & 3.968 & 843 & 401 & 1053.05 & 4956,70 & 10420,19 \\
2008 & 4.249 .117 & 4.059 & 908 & 460 & 1046.84 & 4679,64 & 9237,21 \\
2009 & 4.319 .142 & 4.046 & 1.022 & 474 & 1067.51 & 4226,17 & 9112,11 \\
2010 & 4.395 .983 & 4.097 & 1.079 & 471 & 1072.98 & 4074,13 & 9333,30 \\
2011 & 4.477 .384 & 4.169 & 1.082 & 499 & 1073.97 & 4138,06 & 8972,71 \\
\hline
\end{tabular}

\section{TEMUAN DAN PEMBAHASAN}

Estimasi untuk menjawab ketiga tujuan penelitian dilakukan dengan mengklasifikasikan 13 kabupaten kota di kalimantan barat berdasarkan 3 tipologi, yaitu (1) tipologi pertumbuhan ekonomi dan pendapatan perkapita; (2) tipologi hdi dan pendapatan perkapita; dan (3) tipologi HDI dan pertumbuhan ekonomi.

\subsection{Pertumbuhan Ekonomi dan Pendapatan Perkapita}

Kabupaten/kota di Kalimantan Barat dapat diklasifikasikan pada empat kuadran seperti berikut (lihat lampiran 1). Kuadran 1 menggambarkan kabupaten/kota dengan pertumbuhan ekonomi tinggi dan pendapatan perkapita tinggi. Kuadran 2 menggambarkan kabupaten/kota dengan pertumbuhan ekonomi rendah dan pendapatan perkapita tinggi. Kuadran 3 menggambarkan kabupaten/kota dengan pertumbuhan ekonomi rendah dan pendapatan perkapita rendah. Kuadran 4 menggambarkan kabupaten/kota dengan Pertumbuhan ekonomi tinggi dan pendapatan perkapita rendah.

\section{Tabel 5.Tipologi Kabupaten/Kota Di Kalimantan BaratMenurut Pertumbuhan Ekonomi dan PDRB/Kapita}

\begin{tabular}{|c|c|c|}
\hline \multirow[t]{2}{*}{ PertumbuhanEkonomi } & \multicolumn{2}{|c|}{ PDRB/Kapita } \\
\hline & $(y i>y)$ & $(\mathbf{y i}<\mathbf{y})$ \\
\hline$(\mathbf{r i}>\mathbf{r})$ & $\begin{array}{l}\text { Pendapatan perkapita tinggi \& } \\
\text { pertumbuhan tinggi: } \\
\text { Sambas } \\
\text { Ketapang } \\
\text { Kota Singkawang } \\
\text { Kota Pontianak }\end{array}$ & $\begin{array}{l}\text { Pendapatanperkapita rendah } \& \\
\text { pertumbuhan tinggi: } \\
\text { Bengkayang } \\
\text { Sekadau }\end{array}$ \\
\hline$(\mathbf{r i}<\mathbf{r})$ & $\begin{array}{l}\text { Pendapatan perkapita tinggi } \\
\text { \&pertumbuhan rendah: } \\
\text { Sintang }\end{array}$ & $\begin{array}{l}\text { Pendapatan perkapita rendah } \\
\text { \&pertumbuhan rendah: } \\
\text { Landak } \\
\text { Pontianak } \\
\text { Sanggau } \\
\text { Kapuas Hulu } \\
\text { Melawi } \\
\text { Kayong Utara }\end{array}$ \\
\hline
\end{tabular}


Keterangan:

$\mathrm{r}$ : rata-rata pertumbuhan ekonomi kabupaten/kota

y : rata-rata PDRB per kapita kabupaten/kota

ri : pertumbuhan ekonomi kabupaten/kota yang diamati (i)

yi : PDRB per kapita kabupaten/kota yang diamati (i)

Pembagian kabupaten/kota berdasarkan kombinasi pertumbuhan ekonomi dan pendapatan perkapita mengklasifikasikan 13 kabupaten/kota di Kalimantan Barat sebagaimana terlihat pada Tabel 5. Ketigabelas Kabupaten/Kota yang dianalisis menunjukkan bahwa keempat kategori pilihan seluruhnya terisi. Jumlah kabupaten terbanyak terdapat pada kategori pendapatan perkapita rendah dan pertumbuhan ekonomi rendah, yaitu sebanyak 6 kabupaten (46,15\%). Sebaliknya 23,07\% jatuh pada kategori pendapatan perkapita tinggi dan pertumbuhan ekonomi tinggi. Dua kabupaten terletak pada kategori pertumbuhan ekonomi tinggi dan pendapatan perkapita rendah $(15,38 \%)$. Sedangkan pada kategori pendapatan perkapita tinggi dan pertumbuhan ekonomi rendah terdapat satu kabupaten $(7,69 \%)$.

\subsection{HDI dan Pendapatan Perkapita}

Kabupaten/kota di Kalimantan Barat dapat diklasifikasikan pada empat kuadran seperti berikut (lihat lampiran 2). Kuadran 1menggambarkan Kabupaten/kota dengan HDI tinggi dan pendapatan perkapita tinggi. Kuadran 2 menggambarkan Kabupaten/kota dengan HDI rendah dan pendapatan perkapita tinggi. Kuadran 3 menggambarkan Kabupaten/kota dengan HDIrendah dan pendapatan perkapita rendah. Kuadran 4 menggambarkan Kabupaten/kota dengan HDI tinggi dan pendapatan perkapita rendah.

Tabel 6. Tipologi Kabupaten/Kota Di Kalimantan Barat Menurut HDI dan PDRB/Kapita

\begin{tabular}{|c|c|c|}
\hline \multirow[t]{2}{*}{ HDI } & \multicolumn{2}{|c|}{ PDRB/Kapita } \\
\hline & $(y i>y)$ & $(y i<y)$ \\
\hline$(\mathbf{r i}>\mathbf{r})$ & $\begin{array}{l}\text { Pendapatan perkapita tinggi } \& \text { HDI } \\
\text { tinggi: } \\
\text { Kota Singkawang } \\
\text { Kota Pontianak }\end{array}$ & $\begin{array}{l}\text { Pendapatan perkapita rendah \&HDI } \\
\text { tinggi: } \\
\text { Pontianak } \\
\text { Sanggau } \\
\text { Kapuas Hulu }\end{array}$ \\
\hline$(\mathbf{r i}<\mathbf{r})$ & $\begin{array}{l}\text { Pendapatan perkapita tinggi \&HDI } \\
\text { rendah: } \\
\text { Sambas } \\
\text { Ketapang } \\
\text { Sintang }\end{array}$ & $\begin{array}{l}\text { Pendapatan perkapita rendah \&HDI } \\
\text { rendah: } \\
\text { Bengkayang } \\
\text { Landak } \\
\text { Sekadau } \\
\text { Melawi } \\
\text { Kayong Utara }\end{array}$ \\
\hline
\end{tabular}

Keterangan:

$r$ : rata-rata HDI kabupaten/kota

y : rata-rata PDRB per kapita kabupaten/kota 
ri : HDI kabupaten/kota yang diamati (i)

yi : PDRB per kapita kabupaten/kota yang diamati (i)

Pembagian kabupaten/kota berdasarkan kombinasi pertumbuhan ekonomi dan pendapatan perkapita mengklasifikasikan 13 kabupaten/kota di Kalimantan Barat sebagaimana terlihat pada Tabel 6. Data dari 13 Kabupaten/Kota yang dianalisis menunjukkan bahwa keempat kategori pilihan seluruhnya terisi. Jumlah kabupaten terbanyak terdapat pada kategori pendapatan perkapita rendah dan HDI rendah, yaitu sebanyak 5 kabupaten $(38,46 \%)$. Sebaliknya hanya $15,38 \%$ jatuh pada kategori pendapatan perkapita tinggi dan HDI tinggi (2 kabupaten). 3 kabupaten terletak pada kategori HDI tinggi dan pendapatan perkapita rendah $(23,08 \%)$. Sedangkan pada kategori pendapatan perkapita tinggi dan HDI rendah juga terdapat 3 kabupaten $(23,08 \%)$.

\subsection{HDI dan Pertumbuhan Ekonomi}

Kabupaten/kota di Kalimantan Barat dapat diklasifikasikan pada empat kuadran seperti berikut (lihat lampiran 3). Kuadran 1 menggambarkan kabupaten/kota dengan HDI tinggi dan pertumbuhan ekonomi tinggi. Kuadran 2 menggambarkan kabupaten/ kota dengan HDI rendah dan pertumbuhan ekonomi tinggi. Kuadran 3 menggambarkan kabupaten/kota dengan HDI rendah dan pertumbuhan ekonomi rendah. Kuadran 4 menggambarkan kabupaten/kota dengan HDI tinggi dan pertumbuhan ekonomi rendah.

Tabel 7. Tipologi Kabupaten/Kota Di Kalimantan Barat Menurut HDI dan Pertumbuhan Ekonomi

\begin{tabular}{|c|c|c|}
\hline \multirow{2}{*}{$\begin{array}{c}\text { Pertumbuhan } \\
\text { Ekonomi }\end{array}$} & \multicolumn{2}{|c|}{ HDI } \\
\hline & $(y i>y)$ & $(y i<y)$ \\
\hline$(\mathbf{r i}>\mathbf{r})$ & $\begin{array}{l}\text { Pertumbuhan ekonomi tinggi \& } \\
\text { HDI tinggi: } \\
\text { Kota Pontianak } \\
\text { Kota Singkawang }\end{array}$ & $\begin{array}{l}\text { Pertumbuhan ekonomi rendah \& } \\
\text { HDI tinggi: } \\
\text { Pontianak } \\
\text { Sanggau } \\
\text { Kapuas Hulu }\end{array}$ \\
\hline$(\mathbf{r i}<\mathbf{r})$ & $\begin{array}{l}\text { Pertumbuhan ekonomi tinggi \& } \\
\text { HDI rendah: } \\
\text { Sambas } \\
\text { Bengkayang } \\
\text { Sekadau } \\
\text { Ketapang }\end{array}$ & $\begin{array}{l}\text { Pertumbuhan ekonomi rendah \& } \\
\text { HDI rendah: } \\
\text { Landak } \\
\text { Sintang } \\
\text { Melawi } \\
\text { Kayong Utara }\end{array}$ \\
\hline
\end{tabular}

\footnotetext{
Keterangan:

$\mathrm{r}$ : rata-rata pertumbuhan ekonomi kabupaten/kota

y : rata-rata HDI kabupaten/kota

ri : pertumbuhan ekonomi kabupaten/kota yang diamati (i)

yi : HDI kabupaten/kota yang diamati (i)
} 
Pembagian kabupaten/kota berdasarkan kombinasi pertumbuhan ekonomi dan pendapatan perkapita mengklasifikasikan 13 kabupaten/kota di Kalimantan Barat sebagaimana terlihat pada Tabel 7. Data dari 13 Kabupaten/Kota yang dianalisis menunjukkan bahwa keempat kategori pilihan seluruhnya terisi. Jumlah kabupaten terbanyak terdapat pada kategori pertumbuhan ekonomi rendah dan HDI rendah, yaitu sebanyak 4 kabupaten (30,77\%). Sebaliknya hanya 15,38\% jatuh pada kategori pertumbuhan ekonomi tinggi dan HDI tinggi (2 kabupaten). Empat kabupaten terletak pada kategori HDI tinggi dan pertumbuhan ekonomi rendah (30,77\%). Sedangkan pada kategori pertumbuhan ekonomi tinggi dan HDI rendah juga terdapat 4 kabupaten $(30,77 \%)$.

\subsection{Pembahasan}

Hasil estimasi memperlihatkan inkonsistensi indikator makro dan pembangunan pada beberapa kabupaten, sedangkan kabupaten lain memiliki konsistensi. Dua daerah yang secara konsisten berada pada kuadran tertinggi, yaitu kombinasi "pendapatan perkapita tinggi-HDI tinggi-pertumbuhan ekonomi tinggi" adalah Kota Pontianak dan Kota Singkawang. Sedangkan daerah yang secara konsisten berada pada kuadran terendah, yaitu kombinasi "pendapatan perkapita rendah-HDI rendah-pertumbuhan ekonomi rendah" adalah Kabupaten Landak dan Kabupaten Kayong Utara. Sedangkan sembilan kabupaten lain berada di antara kedua kategori di atas.

Kedua daerah yang secara konsisten menunjukkan performa yang tinggi adalah daerah kota, baik ibukota Propinsi Kalimantan Barat, yaitu Kota Pontianak maupun bukan ibukota, yaitu Kota Singkawang. Hal ini mudah dipahami, mengingat perkotaan merupakan pusat pemerintahan serta pusat kegiatan ekonomi yang umumnya dilengkapi dengan infrastruktur yang baik untuk menunjang kegiatan ekonomi tersebut. Kota Pontianak dan Kota Singkawang memiliki luas wilayah terkecil di Kalimantan Barat jika dibandingkan dengan kabupaten lain, oleh karena itu perekonomian tidak bertumpu pada sector pertanian, melainkan pada sektor jasa (non-tradable sector).

Tingginya pendapatan perkapita dan pertumbuhan ekonomi ini tercermin pula pada kualitas manusianya yang diukur dari Indeks Pembangunan Manusia (HDI). Ini berarti tingginya pendapatan yang terus meningkat dari waktu ke waktu berasosiasi positif terhadap peningkatan kualitas hidup masyarakat di Kota Pontianak dan Singkawang. Peningkatan kemampuan secara ekonomi memberikan akses yang lebih luas bagi masyarakat untuk mendapatkan pendidikan dan pelayanan kesehatan. Pada gilirannya hal ini akan meningkatkan lama sekolah, meningkatkan angka melek huruf, menurunkan angka kematian bayi/balita serta meningkatkan pengeluaran perkapita. Secara bersama-sama komponen ini akan meningkatkan HDI Kota Pontianak dan Kota Singkawang.

Tiga kabupaten yang memiliki performa rendah baik dilihat dari pertumbuhan ekonomi, pendapatan perkapita maupun HDI adalah Kabupaten Landak, Kabupaten 
Melawi dan Kabupaten Kayong Utara. Ketiga kabupaten ini merupakan kabupaten baru hasil pemekaran. Kabupaten Landak merupakan kabupaten hasil pemekaran Kabupaten Pontianak pada tahun 1999, Kabupaten Melawi merupakan kabupaten hasil pemekaran Kabupaten Sintang pada tahun 2004, sedangkan Kabupaten Kayong Utara merupakan hasil pemekaran Kabupaten Ketapang pada tahun 2007. Ketiga kabupaten ini masih mengandalkan sektor pertanian sebagai penggerak utama perekonomian.

Karakteristik wilayah ketiga kabupaten ini berbeda, dimana Kayong Utara dikategorikan daerah pesisir pantai, sedangkan Kabupaten Landak dan Kabupaten Melawi dikategorikan daerah pedalaman. Umumnya daerah pesisir pantai relative lebih maju dibanding daerah pedalaman, namun demikian untuk kasus Kabupaten Ketapang dan sekitarnya (Kayong Utara dan Kendawangan), keunggulan lokasi ini terhambat oleh terisolirnya ketiga wilayah tersebut dengan wilayah Kalimantan Barat lainnya. Sehingga kegiatan ekonomi tidak dapat berkembang dengan pesat disebabkan kurangnya dukungan infrastruktur untuk menghubungkan wilayah selatan Kalimantan Barat ini dengan bagian tengah dan utara. Hal inilah yang menjadi salah satu kendala perkembangan ekonomi Kabupaten Ketapang dan sekitarnya, termasuk Kabupaten Kayong Utara.

Kabupaten Sambas dan Ketapang memiliki pola yang menarik yaitu "pertumbuhan ekonomi tinggi-pendapatan perkapita tinggi-HDI rendah". Dalam berbagai pembahasan ilmu ekonomi pembangunan, keselarasan antara pertumbuhan ekonomi dan HDI memang sering dipertikaikan. Ketidaksesuaian antara capaian ekonomi yang diukur dengan pertumbuhan ekonomi dan pendapatan perkapita ini menunjukkan rendahnya keterlibatan masyarakat dalam berkontribusi dalam pembangunan sehingga hasil pembangunan hanya dinikmati oleh sebagian kecil masyarakat saja. Hal ini mengakibatkan capaian indikator-indikator pengukur keberhasilan HDI tidak memuaskan. Apabila masyarakat ikut serta dalam penciptaan PDRB, mereka akan memiliki pendapatan yang cukup untuk mengakses fasilitas pendidikan dan kesehatan dan pada gilirannya meningkatkan produktivitasnya untuk menghasilkan PDRB yang lebih tinggi lagi bagi daerah tersebut.

Selain itu terdapat kemungkinan mekanisme transfer kurang berjalan secara efektif. Seyogyanya perekonomian yang memiliki PDRB tinggi dan terus tumbuh akan mendapatkan penghasilan pajak yang tinggi yang akan disalurkan kepada masyarakat yang tidak mampu sehingga mereka dapat mengakses fasilitas kesehatan, pendidikan dan mendapatkan bantuan ekonomi untuk memenuhi kebutuhan dasarnya sehari-hari. Apabila hal ini terpenuhi, maka capaian indikator pengukur HDI akan meningkat dan menghasilkan masyarakat yang lebih berkualitas.

Sebaliknya 3 kabupaten berada pada kategori "Pertumbuhan ekonomi rendahpendapatan perkapita rendah-HDI tinggi”. Kondisi di Kabupaten Pontianak, Kabupaten Kapuas Hulu dan Kabupaten Sanggau ini berlawanan dengan Kabupaten Sambas dan Kabupaten Ketapang. Meskipun berada di bawah rata-rata kabupaten lain, dengan 
keterbatasannya ketiga kabupaten ini mampu meningkatkan HDInya sehingga berada di atas rata-rata kabupaten lain di Kalimantan Barat. Hal ini merupakan fenomena yang menarik dimana logika umum adalah perekonomian yang memiliki PDRB rendah biasanya memiliki kualitas sumberdaya manusia yang rendah pula. Namun demikian apabila kebijakan peningkatan kualitas sumberdaya manusia dilaksanakan secara terarah, maka dengan dana yang terbatas, upaya tersebut dapat berjalan dengan efektif. Keefektifan kebijakan untuk peningkatan pendidikan dan kesehatan ini pada gilirannya dapat mengatasi kekurangan dalam bidang ekonomi. Sehingga secara total HDI mengalami peningkatan yang signifikan.

Dua kabupaten, yaitu Kabupaten Bengkayang dan Kabupaten Sekadau memiliki kesamaan yaitu "pendapatan perkapita rendah-HDI rendah tetapi pertumbuhan ekonomi tinggi". Rendahnya HDI yang berasosiasi dengan rendahnya PDRB perkapita, namun demikian pertumbuhan ekonomi yang tinggi merupakan peluang untuk meningkatkan pendapatan perkapita serta HDI. Hal ini dapat dicapai apabila peningkatan PDRB tersebut dicapai dengan memberikan kesempatan sebanyak mungkin kepada masyarakat untuk turut serta dalam penciptaan barang dan jasa. Dengan demikian masyarakat akan ikut menikmati hasil pembangunan yang tercermin dari pengeluaran perkapita mereka. Selain itu peningkatan pendapatan perkapita yang dinikmati secara merata akan meningkatkan akses terhadap fasilitas kesehatan dan pendidikan. Strategi pembangunan harus diarahkan pada upaya untuk menyelaraskan pencapaian di bidang ekonomi dan pembangunan manusia.

Kabupaten Sintang menghadapi situasi yang sedikit berbeda dimana pendapatan perkapita tinggi, namun pertumbuhan ekonomi dan HDI masih rendah. Dalam jangka panjang hal ini akan menjadi masalah sebab kabupaten lain mengalami pertumbuhan ekonomi yang tinggi. Dengan demikian Kabupaten Sintang akan semakin tertinggal. Upaya yang serius perlu dilakukan untuk menciptakan pertumbuhan sekaligus mengarahkan pertumbuhan tersebut untuk perbaikan kualitas sumberdaya manusia. Saat ini pendapatan perkapita yang tinggi belum diimbangi dengan kualitas sumberdaya manusia yang tinggi sebagaimana tercermin dari HDI yang rendah.

Upaya untuk mencapai pertumbuhan tinggi, pendapatan perkapita tinggi serta HDI tinggi untuk Kalimantan Barat memerlukan strategi yang mengarah pada konvergensi dalam ketiga bidang tersebut. Kabupaten/kota yang sudah memiliki performa yang tinggi dalam ketiga komponen tersebut perlu memelihara momentum. Sedangkan kabupaten/kota yang sudah memiliki pertumbuhan ekonomi yang tinggi tetapi masih memiliki HDI yang rendah perlu memfokuskan pada upaya memeratakan pertumbuhan dan peningkatan kualitas SDM. 
Tabel 8.Ringkasan Perbandingan Antar Kabupaten/KotaKalimantan Barat

\begin{tabular}{|c|c|c|c|c|}
\hline Kabupaten/Kota & $\begin{array}{l}\text { Pertumbuhan } \\
\text { Ekonomi }\end{array}$ & $\begin{array}{l}\text { Pendapatan } \\
\text { Perkapita }\end{array}$ & HDI & Strategi Pembangunan \\
\hline Kota Pontianak & Tinggi & Tinggi & Tinggi & Memelihara momentum \\
\hline Kota Singkawang & Rendah & Tinggi & Tinggi & Memelihara momentum \\
\hline Kabupaten Landak & Rendah & Rendah & Rendah & $\begin{array}{l}\text { Mengejar pertumbuhan, } \\
\text { pemerataan dan HDI }\end{array}$ \\
\hline Kabupaten Melawi & Rendah & Rendah & Rendah & $\begin{array}{l}\text { Mengejar pertumbuhan, } \\
\text { pemerataan dan HDI }\end{array}$ \\
\hline $\begin{array}{l}\text { Kabupaten Kayong } \\
\text { Utara }\end{array}$ & Rendah & Rendah & Rendah & $\begin{array}{l}\text { Mengejar pertumbuhan, } \\
\text { pemerataan dan HDI }\end{array}$ \\
\hline Kabupaten Sambas & Tinggi & Tinggi & Rendah & $\begin{array}{l}\text { Orientasi pada pemerataan dan } \\
\text { peningkatan HDI }\end{array}$ \\
\hline $\begin{array}{l}\text { Kabupaten } \\
\text { Ketapang }\end{array}$ & Tinggi & Tinggi & Rendah & $\begin{array}{l}\text { Orientasi pada pemerataan dan } \\
\text { peningkatan HDI }\end{array}$ \\
\hline $\begin{array}{l}\text { Kabupaten } \\
\text { Pontianak }\end{array}$ & Rendah & Rendah & Tinggi & $\begin{array}{l}\text { Mengejar pertumbuhan dan } \\
\text { pemerataan bermodalkan sdm } \\
\text { berkualitas }\end{array}$ \\
\hline $\begin{array}{l}\text { Kabupaten Kapuas } \\
\text { Hulu }\end{array}$ & Rendah & Rendah & Tinggi & $\begin{array}{l}\text { Mengejar pertumbuhan dan } \\
\text { pemerataan bermodalkan sdm } \\
\text { berkualitas }\end{array}$ \\
\hline Kabupaten Sanggau & Rendah & Rendah & Tinggi & $\begin{array}{l}\text { Mengejar pertumbuhan dan } \\
\text { pemerataan bermodalkan sdm } \\
\text { berkualitas }\end{array}$ \\
\hline $\begin{array}{l}\text { Kabupaten } \\
\text { Bengkayang }\end{array}$ & Tinggi & Rendah & Rendah & $\begin{array}{l}\text { Memelihara momentum } \\
\text { pertumbuhan dan mengarahkan } \\
\text { pada pemerataan dan HDI }\end{array}$ \\
\hline Kabupaten Sekadau & Tinggi & Rendah & Rendah & $\begin{array}{l}\text { Memelihara momentum } \\
\text { pertumbuhan dan mengarahkan } \\
\text { pada pemerataan dan HDI }\end{array}$ \\
\hline Kabupaten Sintang & Rendah & Tinggi & Rendah & $\begin{array}{l}\text { Mengejar pertumbuhan dan } \\
\text { mengarahkan pada perbaikan } \\
\text { HDI }\end{array}$ \\
\hline
\end{tabular}

\section{KESIMPULAN}

Terdapat ketimpangan pembangunan Kalimantan Barat antara Kota (Pontianak dan Singkawang) dan kabupaten lainnya dimana wilayah kota memiliki performa yang tinggi dalam pertumbuhan ekonomi, pendapatan perkapita maupun HDI. Tidak satupun kabupaten yang memiliki performa tinggi dalam ketiga indikator sekaligus. Sebelas 
kabupaten lain yang dianalisis memiliki performa yang beragam. Tiga kabupaten memiliki performa yang rendah pada ketiga indikator yaitu pertumbuhan ekonomi, pendapatan perkapita dan HDI. Ketiga kabupaten ini adalah Kabupaten Landak, Kabupaten Melawi dan Kabupaten Kayong Utara yang merupakan kabupaten hasil pemekaran.

Kabupaten memiliki HDI yang tinggi meskipun pertumbuhan ekonomi dan pendapatan perkapitanya rendah. Ketiga kabupaten ini adalah Kabupaten Pontianak, Kabupaten Kapuas Hulu dan Kabupaten Sanggau. Sebaliknya Kabupaten Sambas dan Kabupaen Ketapang, meskipun memiliki pertumbuhan ekonomi dan pendapatan perkapita yang tinggi ternyata memiliki HDI yang rendah. Kabupaten Sintang, Bengkayang serta Sekadau juga memiliki HDI yang rendah baik disebabkan oleh pertumbuhan ekonomi yang rendah ataupun pendapatan perkapita yang rendah.

Kebijakan pembangunan pada tingkat kabupaten dan kota harus mengacu pada tujuan pembangunan baik pada skala lokal, provinsi maupun nasional dengan pola yang konvergen. Hal ini akan memudahkan pengembangan wilayah pada masa yang akan datang apabila sudah terdapat keseragaman performa/kinerja pembangunan antar daerah.

Kota Singkawang dan Kota Pontianak perlu mempertahankan momentum pertumbuhan ekonomi tinggi yang sudah dicapai dengan tetap memperhatikan pemerataan dan peningkatan kualitas SDM. Kabupaten Landak, Melawi, Kayong Utara, Bengkayang, Sekadau dan Sintang perlu membuat strategi untuk mengejar pertumbuhan dengan mengidentifikasi keunggulan yang dimiliki. Upaya mengejar pertumbuhan harus melibatkan sebanyak mungkin masyarakat melalui peningkatan kesempatan kerja (pro growth-pro job strategy). Dengan demikian masyarakat dapat meningkatkan kesejahteraannya yang pada gilirannya meningkatkan kemampuan mereka mengakses fasilitas kesehatan, pendidikan serta meningkatkan pengeluaran perkapita.

Kabupaten Sambas dan Ketapang perlu mengarahkan strategi pembangunan kearah pemerataan dan pembangunan sumberdaya manusia karena kedua kabupaten ini telah mencapai pertumbuhan ekonomi yang tinggi. Berbeda dengan Kabupaten Pontianak, Kabupaten Kapuas Hulu dan Kabupaten Sanggau yang telah mencapai HDI tinggi meskipun memiliki pertumbuhan ekonomi dan pendapatan perkapita yang rendah. Sehingga kebijakan ketiga kabupaten ini harus lebih diarahkan pada upaya mengejar pertumbuhan ekonomi.

\section{DAFTAR PUSTAKA}

Anderson, V. (1991). Alternative Economic Indicator. New York: Routledge.

Bappenas, (2013). Data dan Informasi Kinerja Pembangunan 2004-2012. 
BPS, (2010).Kalimantan Barat Dalam Angka 2010, Badan Pusat Statistik Provinsi Kalimantan Barat, Pontianak.

Batiz, F. L. R.,\& Batiz, L. A. R. (1994). International finance and open economy macroeconomics, Second Edition, , New York: Mac-millan Publishing Company.

Froyen, R.T. (1996).Macroeconomics theories \&policies Fifth Edition. Upper Saddle River: Prentice Hall International Editions.

Frumkin, N. (1990). Guide to economic indicators. New York: M.E. Sharpe Armonk.

Irawan \& Suparmoko, (1992), Ekonomika pembangunan, Edisi V. Yogyakarta: BPFE.

Keynes, J. M. (1936). The general theory of employment, interest and money. Macmillan Cambridge University Press.

Kuncoro, M. (1997).Ekonomi Pembangunan: Teori, Masalah, dan Kebijakan, Edisi Ketiga, Yogyakarta: UPP AMP YKPN.

Kuncoro, M. (2001).Metode kuantitatif, teori dan aplikasi untuk bisnis dan ekonomi, Edisi Ketiga, Yogyakarta: UPP AMP YKPN.

Kuncoro, M. (2004).Otonomi dan pembangunan daerah, reformasi, perencanaan, strategi dan peluang. Jakarta: Penerbit Erlangga.

Samuelson, P.A., \& Nordhaus, W.D. (1995). Economics, International Edition, Fifteen Edition, New York: Mc Graw Hill.

Smith, A. (1776). An inquiry into the nature and causes of the wealth of nations. University of Chicago Press.

Sukirno, S. (1985).Ekonomi Pembangunan: Proses, Masalah dan Kebijaksanaan. Jakarta: LP FEUI.

Todaro, M. P. \& Smith, S. C. (2012).Economic development $11^{\text {th }}$ Edition. Boston: Addison-Wesley Pearson.

Undang-Undang Nomor 22 Tahun 1999 tentang Pemerintahan Daerah.

Undang-Undang Nomor 25 Tahun 1999 tentang Perimbangan Keuangan Antara Pemerintah Pusat dan Daerah.

Undang-Undang No 32 Tahun 2004 tentang Pemerintahan Daerah

Undang-Undang No 33 Tahun 2004 tentang Perimbangan Keuangan Antara Pemerintah Pusat dan Daerah. 